\title{
Community Policing for Conflict Resolution and Community Resilience
}

\author{
Vinita Pandey \\ Department of Sociology, Nizam College, Osmania University, Hyderabad, India \\ *Corresponding Author: pandeyvini@gmail.com
}

\begin{abstract}
In many parts of the globalized world, there has been an escalation in conflicts with multi levels of chaos and anarchy leading to huge loss of lives, economic slowdown and most sadly, a sense of fear and uncertainty in the community. Within the third world, ethnic clashes and communal violence are being classed as equal to the threats of terrorism. Efforts of the law enforcing agencies are constantly challenged to resolve community oriented conflicts on their own. Emerging models of conflict resolution to ensure normative order and community resilience require the communities to be their partners. There is an increasing need for the police as the law-enforcing agency to transform into a community-oriented agency since the ground of enforcement is community. The dismal policepopulation ratio in India (106 police personnel per 0.1 million population) has not only over-burdened the critical forces but have been influencing their performance immensely. In this background, the paper argues how community policing can provide a new perspective with multiple benefits of conflict resolution, peace building, community resilience and most significantly community empowerment. The research is based on an empirical study (based on 10 focus group discussions and in-depth interviews) in Hyderabad, joint capital of the newly formed Telangana and Andhra Pradesh states. The sample includes all ranks of police personnels from constables (staff of police station and lowest in hierarchy) to Director General of Police (DGP - in charge of state police force). The findings indicate that community policing can be an important strategy, an instrumental philosophy, and hope and action for conflict resolution and community resilience.
\end{abstract}

Keywords Community Policing, Crime, Conflict Resolution, Community Empowerment, Resilience

\section{Introduction}

Policing as a law enforcement activity is a challenging task owing to multitude of significant responsibilities including the maintenance of law and order and conflict resolution. Police officers are regularly called upon to deal with conflict situations. These conflicts range from acting as a mediator in a domestic dispute, to restoring order in a pub brawl (Braithwaite, 1996). Police forces are a very significant part of any community and therefore, the cordial and amicable relations between the police and the community remain vital for not only controlling any crime but also in resolving conflict.

With spurt of conflicts and crimes at various levels and diversified forms, the task of policing is getting tougher, demanding and difficult. At community level, the sources of conflict ranges from trivial to complex property disputes, domestic violence, street fights, crime against children and women; caste, communal and ethnic violence, to the extreme form of conflict spectrum - terrorist attacks. The conflict resolution at community level is under jurisdiction of police agencies. Needless to add that conflict resolution remain vital to impart buoyancy and attain community resilience.

\section{Community Policing}

Community oriented policing has been acknowledged by sociologists, urban planners and law enforcement practitioners as a key tool for establishing a police-community partnership to aid in identifying, prioritizing, and resolving crime problems (Coleman, 1988; 1990) and maintaining law and order. There is a collective collaboration of the police, community residents and other stakeholders including the shopkeepers, hawkers, corporates, and social activists in the implementation of the strategies to prevent crime in an approach. Indeed, this philosophy has been gaining a lot of popularity among the law enforcement circles.

Nicholl (2000) observes that community policing as a policing philosophy is being designed to reduce crime and disorder in communities by fostering trust, respect, and collaboration between the police officers and the citizens. However, community policing is a very broad term often used to describe many aspects of the process by which the police engage with the community in the prevention of crime. At its core is the recognition that by working with the 
community, the law enforcement agencies can find local solutions to local problems. Engaging the community in crime reduction and prevention and conflict resolution allows a more targeted approach to local priorities by empowering the community to identify and respond to local concerns, the benefits of which can be widespread.

Police and members of the community come together, take collective decisions, and solve the problems of crime, conflicts and disorder through collective actions. This requires the existence of shared norms, network based trust, and participation. Community policing is not just about police departments implanting new programs and getting out of their cars, but, perhaps more importantly, involves communities taking the initiative to come forward and work with the police. It is also believed that community policing, as an institutional mechanism, can work toward developing shared norms of safety and networks of trust and participation in communities (Ansari \& Bruell, 2009).

Cordner (1998) determined that there are essentially four facets of community policing: the philosophical, where the community's role is fundamental and the police's role is expanded from traditional policing duties; the strategic, where ideas from the community policing are developed into strategies for practice (Bennet 1998 p. 48); the tactical, which focuses on the implementation of the strategies developed; and the organizational; where the support offered at an organizational level should be encouraged to promote community policing.

Advocates for community policing have highlighted many reasons why community policing is beneficial to the society. These arguments are broken down into three areas:

\section{Community-specific advantages}

- Mobilization and empowerment of communities to identify and respond to concerns

- Improved local physical and social environment

- Increase in positive attitudes towards police

- $\quad$ Reduced fear of crime and conflicts (Segrave \& Ratcliffe, 2004, pp. 5-6).

\section{Police-specific benefits}

- Improved police-community relationship

- Improved community perception of police 'legitimacy'

- An increase in officer satisfaction with their work (Segrave \& Ratcliffe, 2004, pp. 5-6).

\section{Shared benefits}

- A decreased potential for police-citizen conflict

- A reduction in crime rates

- A better flow of information between the police and the community

- Better implementation of crime prevention and crime control activities, as a result, both parties work towards shared goals (Segrave and Ratcliffe 2004, pp. 5-6).
The benefits thus offered by community policing initiatives are multiple. Keeping in view the benefits of such an approach, the Hyderabad Police launched its own initiative named Maithri, which means friendship.

\section{Community Policing in Hyderabad}

"Maithri" was launched in the year 2000 with the mission to render courteous, compassionate and caring responsive police personnel and increase public confidence in police with respect to maintenance of peace and order and a feeling of safety from crime. It rests on the belief that contemporary community problems require a decentralized and personalized police approach, which involves citizens in the process of policing themselves.

The process of Maithri can be understood by using the acronym CAMP that is:

- Consultation: The community is consulted on a regular basis to know and enumerate all their felt needs and they are actively encouraged to suggest all possible legally acceptable solutions.

- Adaptation: Adaptation means changing or devising new policing methods and adopting appropriate legal procedures for solving the local problems.

- Mobilization: Once the felt needs of the community and their solutions are identified, necessary labor, material and financial resources are mobilized for implementing the solution.

- Problem Solving: After the resources are mobilized, the actual work of solving the problem is launched and completed. (Mukherjee, 2004)

\section{Methodology}

This research is based on the understanding of the role of community policing in Hyderabad in conflict resolution and community resilience, which are imperative for community empowerment. The study aims to understand the perceptions of police personnel at different ranks and community members from different socio-economic background.

For the purpose of the research, five police divisions of North, East, West, South and Central Zone in Hyderabad were selected. The method used in the study was Focus Group Discussions (FGDs) and in-depth interviews.

Multistage sampling was used to select the police stations from each zone. A multi-stage sample is one in which sampling is done sequentially across two or more hierarchical levels, (in this case, at the division level second at the block level, and third at the area level). Purposive sampling was used for in-depth interviews from police personnels and participants for community FGDs. Also known as judgmental, selective or subjective sampling, purposive sampling relies on the judgment of the researcher when it comes to selecting the units (e.g., people, cases/organisations, events, pieces of data) that are to be studied. 
10 FGDs were conducted with each FGD comprising of 6-8 members. The sample size was 73 and the respondents were police personnels from different ranks and the community members from different socio-economic background. The age composition of the respondents is in between $22-76$ years.

\section{Discussion}

The hierarchical structure of the police in India follows a vertical alignment consisting of senior officers drawn from the Indian Police Service (IPS) who do the supervisory work, the "upper subordinates" (inspectors, sub-inspectors, and asst. sub-inspectors) who work generally at the police station level, and the police constabulary, who are delegated for duties like patrolling, surveillance, guard duties, and law and order work. The constabulary accounts for almost $88 \%$ of the total police strength.

The FGDs started with seeking opinions and insights from the community and police participants about their perception about policing, role of community policing in conflict resolution and building up of community resilience and the ways to overcome challenges posed in community policing.

\section{Perceptions about Policing}

The FGDs and in depth interviews clearly indicated that the aim of policing is to maintain peace and harmony in the community and to ensure that members pursue their avocations without distraction. Secondly, that policing also ensures that community members adhere to the laws.

The former Director General of Police (DGP) in an interview in August 2014 opined that policing should be reformative but the ground reality may not reflect the same. Mostly policing is perceived as penalizing. He extended his argument by saying that community in general hates two things, one is lawbreakers and the other one is law enforcers. We are law enforcers and the answer is implied in this.

According to a 24-year, young police service aspirant policing is quite a tough job. He said police find themselves in an extremely unenviable position, with no great incentives for those who work sincerely. Their success and efforts in preventing riots goes unnoticed. Moreover, their failure is not tolerated. A similar reflection was observed in a FGD with constables who lamented that both ruling and the opposition blame the police; A constable who was also a Maitreyi member argued "Why us? Why is it that our work gets unnoticed?" The group conveyed aggressively the menial tasks performed by the constabulary including physically lifting the dead bodies in accident cases. The community members are apprehensive and do not want to get involved in judicial cases.

There were perceptions in the FGDs of the community, which saw the police department as a highly corrupt institution, disinterested in work, though the degree varies. Infact 56 participants out of 73 (comprising of both police personnel of different levels and community members from different occupational backgrounds) opined that police are corrupt - starting from the constables onwards to high status officers, everyone takes bribe. What is surprising and distressing is that the police take money from both the accused and the complainants. Cases of taking 'hafta' (weekly fixed amount) from the shopkeepers, hawkers are some of the common cases of corruption. (Lamani and Venumadhava, 2013). In the police departments, the rate varies for a constable from INR10 to INR 2, 000, for a sub-Inspector, and an inspector, the range is from INR2, 000 to INR10, 000, while for a deputy superintendent and superintendent, the rate ranges from INR 10,000 to INR 20,000 and may escalate even more (Ahuja, 2006) depending on the nature of the case.

Besides, poor salary structures, nature and hours of duty, accommodation problem apace with certain administrative and organizational problems are the other factors responsible for corruption in the police system. Scholars argue that growing influence of unscrupulous public men and politicians further contribute to corruption in police force (Qadri, 1994).

Highlighting the positive perception about policing, an IT professional asserted that the police are overburdened. The dimensions of gravity of the complaint, political pressure, workload, personnel crunch are the key determinants in the reaction of police towards a particular incident. She opined that community had a major say in law and order before the modern policing arrived. Modern policing divorced the role of community from maintaining law and order. Since community sees police as an external entity, it conveniently blames the police without understanding its own responsibility.

\section{Community Policing in Conflict Resolution and Community Resilience}

The main thrust of the study was to understand how community policing could be a strategy in conflict resolution and community resilience. In the Indian context, the sources of social conflict are primarily rooted in ethnicity, caste, domestic violence, terrorist activities, etc in which police is an important restraining force. It is vital to reduce the vulnerability of the community to enhance inclusive growth. Community resilience is thus an important approach in conflict resolution and community policing.

The idea of community resilience has largely evolved from the writings on social resilience. Adger (2000) defines social resilience as: "the ability of groups or communities to cope with external stresses and disturbances as a result of social, political, and environmental change." Folke (2006) describes social resilience as the necessity of human systems to learn to manage by change and implies that "uncertainty and surprise are part of the game." Community resilience places special emphasis on a community's social capital.

In all the FGDs, communal violence was identified as the principal source of conflict and threat to internal security. The impact of communal violence is severe not only in terms of the loss of life and property but also in terms of the 
damage it causes to the social fabric. Communal conflicts disempower the communities and become major hindrances in development.

The communal violence though predominant in the old city of Hyderabad, it does affect other communally sensitive areas of the city. Different scholars have approached the problem of communal violence with different perspectives, attributing different causes and suggesting different measures to counter it. The Marxist school relates communalism to economic deprivation and to the class struggle between the haves and the have-not's to secure a monopoly control of the market forces. Political scientists view it as a power struggle. Sociologists see it as a phenomenon of social tensions and relative deprivations. The religious experts perceive it as a diadem of violent fundamentalists and conformists. The class analysis of communalism requires some attention. The explanation is that the economic, social and political situations in a society sometimes create such problems and crises for the people that even though they try to grip these crises, they fail to do so. Without attempting to grasp the real causes for this failure, they 'perceive' the other community (numerically much stronger than their own) as the cause of their woes. Communalism is thus a social reality, which is generated and reflected in a distorted way.

There is evidence of the community policing in successfully handling the communal conflicts in Hyderabad. One such enterprise was creating working groups or committees to oversee and address the communally sensitive concerns not only during festivals but also in times of peace and conflict.

Mohalla Committees and peace committees are especially relied upon and trained to deal with communal issues or local issues. Several festivals in Hyderabad are celebrated at community level (Ganesh Festival, Durga Puja, Ramzaan, Bonalu, Moharram, etc) by putting up idols on the roadside and in colonies in temporary pandaals.

In Ganesh festival and Durga Puja, the idols of Lord Ganesh and Goddesses Durga are immersed at the end of the 9-day festival in huge processions. The procession passes from communally sensitive areas, which are thickly populated by Hindu and Muslim communities. It then becomes a huge challenge to retain communal harmony and peace. With the active and enhanced role of the Mohalla and peace committees, these processions in the past one decade have been carried out without any incident of violence or disturbance. In many instances, the festivals of Hindu and Muslim communities in Hyderabad coincide. The initiatives through community policing have been instrumental in preventing any conflicts and thus building in community resilience.

The findings of three FGDs conducted in the Charminar area of Hyderabad highlights that in the past 4-5 years during Hindu and Muslim festivals, the youngsters of the respective communities (Hindu and Muslim) take out bike rallies and unfurl flags to symbolize their respective communities.
Several derogatory slogans against each other are not only the simple acts of provocation but also these slogans can act as weapons to disturb the peace and harmony. Unfortunately, these cultural celebrations are also used as occasions to show the political might and power. A similar celebration in 2010 and 2011 lead to serious communal riots leading to almost a week's curfew in several parts of the old city of Hyderabad. The police in Hyderabad as a part of the community policing inventiveness involved the community elders to have check and counsel their youngsters to prevent any kind of communal conflict or violence.

A trainer at National Police Academy, Hyderabad in an interview in August 2014 observed that the community conflicts are the manifestations of disconnect of people from governance. These communal conflicts are also a reflection of failure of politicians and bureaucracy. If unattended, these conflicts may also lead to serious internal security problems. Nevertheless, these failures are often labelled with their fancy names: naxalism, left wing extremism, etc. It can be easily argued that these failures stem from bad policy and implementation. Stakes further perpetuate this. The trainer interviewee feels that community policing is the only way through which one can prevent further disconnect. He torments on the lack of a clear mandate from the government on community policing and opines that community policing is not being nurtured to grow from its infancy.

A senior police officer involved in decision making emphasized that for conflict resolution and building up community resilience, community policing requires a lot of maturity, understanding, commitment and training to dawn the road. Especially while dealing with different communities, which are at the peak of their religious and communal passions, tremendous patience and maturity remains the prerequisite. The police officers tend to be authoritarian. Generally, the police play two types of roles, that of a force and the other that of a service. He said there is a need to have a flexible approach to deal with different situations and bring balance between force and service. He said:

Maitreyi was successful as long as it was taken seriously. During one regime, it was implemented seriously. It depends on the political executive; if he takes the interest then obviously, the bureaucrats will also take special interest.

Another FGD was conducted among a group of postgraduate students and research scholars, who are optimistic about community policing in conflict resolution especially in communal conflicts. A research scholar in her early 30s was very vocal in conveying that there will be no conflicts if the community is proactive, resilient and aspires for harmony. Even if the conflicts arise due to the diversity and complexity in interests and aspirations of the community members, it can be handled through community policing. This group further reckons that if community policing are implemented efficiently, the courts will have less burden. 
Interestingly, in all the FGD findings the respondents were anguished, agonized and distressed with political apathy as well as political instigation that fires communal conflicts in Hyderabad. Communalism is seen as a political doctrine, which makes use of religious-cultural differences to achieve political ends. It was pointed that most of the politicians are not well versed with police operations and matters. If the sensitivity towards the community policing has to be increased, the politicians at the local level should also be involved in community policing, take training with the community members and personnel of the police department.

\section{Overcoming the Challenges in Community Policing}

The FGD findings further reveals that the trust deficit, budgetary constraints, political pressure and lack of commitment on both the sides of the community and the police are hindering the spirit of community policing. Infact many respondents opined that police is complicit in various stages of communal conflicts and violence.

Bringing change in the perception of citizens towards police is a major task. Police should try for an overhaul of their image with socially relevant activities like awareness camps on traffic rules, domestic violence in localities/colonies. Equally significant is to bring change in the working style of police forces. Police as an organization and service is perceived as corrupt and inefficient. In many instances, this is often exaggerated. However, the onus lies on police too to modify this perception to an efficient law enforcer and community friendly force

The challenges in implementing community policing can be taken care with proper planning and perseverance. Community policing should be seen as a process and not an event. As a process, community policing should evolve its philosophy of mutual partnership.

Though the idea of police reforms is not new, there is a serious need to bring reforms in the hierarchical structure, salary structure, need for greater autonomy and streamline the working hours. Expecting courtesy, respect and commitment from the overburdened force and in many cases where the personnel at the lower levels are compelled to work for 16-20 hours at a stretch is inhuman. With these backdrops, a police cannot be made a part of such community policing initiatives as they are bound to fail. Lack of women police in sufficient number is a big drawback to deal with any women related issues. In a country where men are afraid of going to police station or afraid of talking to a policeman, it is unlikely that an average woman will be able to talk to a male police constable. The efforts are being made to ensure that at least $30 \%$ of police force should be women.

Policing should be treated like any other profession to bring in professionalism. The working conditions should be decent enough so that the personnel volunteer to engage with the community.

If community policing is perceived merely as a policy on paper and lacks the spirit, it is bound to fail. The limitations and challenges of community policing can be addressed with concentrated efforts of community, police and political decision makers.

\section{Suggestions to Strengthen Community Policing}

The FGDs with police personnel and community members presented several insights and suggestions to make community policing as strengths based practice for better conflict resolution and building up community resilience. Some of the reflections are presented below:

- The burden of the police force should be addressed at war footing level if community policing has to be successful. The government should focus on filling in the vacancies at various levels. Recruitment should not be viewed only from the perspective of expenditure; it should be also seen as an investment in the socio-economic development of the country.

- Include community policing syllabi in school and college education to sensitize and motivate the children and youth towards building community-police partnerships.

- Media should equally focus on the success stories of community policing instead of constantly flashing the brutality of the forces. An improved line of communication between the media and the police remain paramount.

- The zone wise police stations should organise the awareness programmes pertaining to community policing by involving the educational institutions, teachers and students in that zone. Unfortunately, none of the community FGD participants was aware of Maitreyi, the community policing initiative of Hyderabad police.

- The patrolling personnel/beat level officers should be specially trained in social interactions, communication and interpersonal skills.

- Reward police personnel and the community not only for the bravery but also for their contributions in community policing initiatives.

- Almost all the police personnel FGDs reflected their concern for family. If the families are taken care of, there is a greater commitment for the service. Thus, the Police Wives Association or Police Family Associations should be more than just welfare bodies on paper.

- Police should encourage the community to approach them for any problem. They should become public friendly in order to access maximum contribution from the community. Community has to equally return the gesture.

\section{Conclusions}

The arguments of Segrave and Ratcliffe (2004) with regard to the benefits provided by community policing are 
clear indicator of the fact that community policing by involving community is an important facilitator in community empowerment. All the FGDs and in-depth interviews concluded with a strong agreement that community policing definitely offers police specific, community specific and shared benefits. The FGD findings clearly stated that community policing is a critical step in conflict resolution and building up resilience, which in turn may support community empowerment.

Public safety, conflict resolution and building up community resilience are both a primary responsibility of the local government and a core expectation of the community members. Community policing thus facilitates both the concerns efficiently.

Community policing indeed is an instrumental strategy, a philosophy that provides hope and paves the action for conflict resolution and building up community resilience only if it is nurtured with willingness by all the stakeholders; the willingness which is imperative for community empowerment.

\section{REFERENCES}

Adger, W. N. (2000). Social and ecological resilience: Are they related? Journal of Progress in Human Geography 24(3), 347-364.

Ahuja Ram. (2006) Social problems in India. Jaipur: Rawat Publication.

Ansari, Sami and Bruell, Christopher. "Community Policing and Social Capital: An Interactional Model" Paper presented at the annual meeting of the ASC Annual Meeting, Philadelphia Marriott Downtown, Philadelphia, PA, Nov 04, 2009

Bennet T (1998). Police and public involvement in the delivery of community policing. In. J P Broudeur (Ed), How to recognize good policing: Problems \& issues, Sage \& Police Executive research forum, Thousand Oaks.

Braithwaite Helen. (1996) Police Officer's Behaviours Associated with Successful Conflict Resolution. Paper presented at the Australian Institute of Criminology Conference First Australasian
Women Police Conference Sydney, 29, 30 \& 31 July 1996. Retrieved from

http://www.aic.gov.au/media library/conferences/policewomen/br aith.pdf

Coleman, J.S. (1988), Social capital in the creation of human capital American Journal of Sociology, Vol. 94, pp. S 95-S 120.

Coleman, J.S. (1990), Foundations of Social Theory. Cambridge: The Belknap Press

Cordner G (1998) Community policing: Elements \& effects. In Alpert \& Piquero Community policing: Contemporary readings. Illinois: Waveland Press.

Edwards C. (1999). Changing police theories for 21st century societies. Sydney: Federation Press.

Folke, C. (2006). Resilience: the emergence of a perspective for social-ecological system analyses. Global Environmental Change, 16(3), 253-267.

Lamani Ravikanth and Venumadhava. G.S. (2013). Police Corruption in India .International Journal of Criminology and Sociological Theory, Vol. 6, No. 4, December 2013, 228-234

Mukherjee, Doel. (2004). Retrieved fromttp://www.humanrightsin itiative.org/new/community_policing_experiments_in_india_1.pdf

Nicholl, C. G. (2000), “Community Policing, Community Justice and Restorative Justice: Exploring the Links for the Delivery of a Balanced Approach to Public Safety," Washington, DC: United States Department of Justice, Office of Community Oriented Policing Services

Peak K \& Glensor R. (1999). Community policing \& problem solving: strategies \& practices ( $2^{\text {nd }}$ ed). New Jersey: Prentice Hall.

Qadri Afzal. S M, (1994) Police Corruption: An Analysis. Indian Journal of Criminology, Vol.22 (1). Pp.5-8

Rahtz, H. (2001).Community Policing: A Handbook for cops and supervisors, Criminal justice press pg $123-126$

Segrave M \& Ratcliffe J. (2004). Community Policing: A Descriptive Overview. Canberra: Australian Institute of Criminology

Tiwary, Deeptiman. (February 22, 2014). Only 106 cops per 1 lakh Indians http://timesofindia.indiatimes.com/india/Only-106-co ps-per-1-lakh-Indians/articleshow/30869512.cms 